\title{
Dual application of entomopathogenic nematodes and fungi on immune and antioxidant enzymes of the greater wax moth, Galleria mellonella L.
}

\author{
Sanaa A. M. Ibrahim ${ }^{1 *}$, Hend H. A. Salem² and M. A. Taha²
}

\begin{abstract}
Pathogenicity and immunity effects of both the entomopathogenic nematode, (Heterorhabditis zealandica) and the entomopathogenic fungus (Beauveria bassiana) on the last larval instar of the greater wax moth, Galleria mellonella $\mathrm{L}$. (Lepidoptera: Pyralidae), were investigated. Both pathogens were either applied separately or in a combination. The fungus was inoculated first, followed by the nematode on time manner $0,2,4$, and 6 days. $L C_{50}$ values for both pathogens were calculated and then used for determination of the changes in immune response-mediated phenoloxidase (PO) and detoxifying enzymes glutathione S-transferase (GST) and non-specific esterase (EST) activities. The results indicated that a positive correlation was found between pathogen concentration and host mortality percentage. $\mathrm{LC}_{50}$ values were $6.49 \mathrm{IJs} /$ larva for $\mathrm{H}$. zealandica and $3.1 \times 10^{2}$ conidia/ml for B. bassiana. Synergistic interactions were found in all combined applications. The degree of synergism increased (reaching 100\% mortality), when the nematode was applied 2 days post-fungal infection. PO activity increased significantly $(p<0.05)$ in a time-dependent manner post-B. bassiana infection. In contrary, the combination of $H$. zealandica $+B$. bassiana or $H$. zealandica alone produced a significant suppressive effect on PO activity over time. GST activity increased significantly $(p<0.05)$ in $36 \mathrm{~h}$, then decreased at $48 \mathrm{~h}$ post-combined application, while the fungal infection enhanced significantly GST activity in time-dependent manner than the control and other treatments. EST activity increased significantly $(p<0.05)$ in both combined application and the single nematode infection than the single fungal infection, which increased during the initial period only. The increased mortality rates and suppression of phenoloxidase and glutathione S-transferase enzymes, following the combined application suggests a strong synergistic effect between both pathogens. It could be concluded that the tested combined pathogens are compatible element for integrated pest management.
\end{abstract}

Keywords: Galleria mellonella, Entomopathogenic nematodes, Entomopathogenic fungi, Interaction effects

\section{Background}

The greater wax moth, Galleria mellonella Linnaeus (Lepidoptera: Pyralidae) is one of the most serious pests of honeybee products due to the destructive feeding habit of its larvae. G. mellonella has developed relatively high levels of resistance to insecticides. In addition, the poison residue in the wax is a result of the frequent use of insecticides. Entomopathogenic nematodes and fungi offer

\footnotetext{
*Correspondence: sanareda@yahoo.com

'Agriculture Research Center, Plant Protection Research Institute, Nadi El-said Street-Dokki, Giza, Cairo 12311, Egypt

Full list of author information is available at the end of the article
}

an environmentally safe, food safety, host-specific with a very low risk of attacking non-target organisms or beneficial insects, and IPM-compatible alternative to chemical insecticides for pests control (Grewal et al. 2005).

Entomopathogenic nematodes (EPNs) from the genus Heterorhabditidae are characterized by a symbiotic association with the bacteria of the genus Photorhabdus, in the intestine of the free-living infective juveniles (IJs) of these nematodes (Ansari et al. 2003). The IJs enter the hemocoel of the insect and release the symbiotic bacteria (Kaya and Gaugler, 1993) then multiply in the hemolymph causing insect death within $48-72 \mathrm{~h}$ and 
establishing conditions for nematode development in the cadaver by providing nutrients. Entomopathogenic fungi (EPFs), especially the isolates of Beauveria bassiana are well-known for their pathogenicity against different target pest species (Laznik et al. 2012). Successful infection depends on the adherence and penetration ability of conidia to the host integuments that achieved by the germ tube itself or by the formation of an appressorium that attaches to the cuticle and gives rise to a narrow penetration peg (Wraight et al. 1998). Conidia of EPFs impart mortality in the target pest by overcoming the complicated host defense-related multiple mechanisms (Hussain and Ming-Yi, 2013). This process requires a prolonged period to impart significant mortality in target pest. Consequently, "dual attack" approach in which two biocontrol agents applied to reduce the dose of toxicant and the host killing time of fungal pathogen was studied (Jia et al. 2016).

Hemolymph of insects is a medium for several physiological processes like immune responses and intermediary metabolism. Enzymatic changes in infected larvae would envisage the metabolic stress of the insect experience during the development of pathogen. Many studies have demonstrated the role of enzymes in response to pathogen threat (Müller et al. 2007).

Phenoloxidase (PO) is one of the key enzymes activated via prophenoloxidase (PPO) cascade in the cuticle or the hemolymph of many insects in response to the immune challenge (Gillespie et al. 1997). In the defense process, peptidoglycan recognition protein binds to its respective elicitor and results in the production of inactive prophenoloxidase (proPO). PO is involved in the conversion of phenols to quinones and the subsequent production of melanin which are important during defense against bacterial (gram + and - ) and fungal infection (Eleftherianos and Revenis, 2011).

Moreover, a joint application could easily overcome the host detoxification-related enzymes such as esterase and glutathione S-transferase (Fan et al. 2013). Esterase (EST) is an important detoxifying enzyme in vivo, which hydrolyzes the esteric bond in synthetic chemicals. It is one of the enzymes showing the strongest reaction to environmental stimulation (Hemming and Lindroth, 2000). Non-specific esterases perform important functions in the degradation of toxins of different origins. GST is first of all associated with the participation of these enzymes in insecticide degradation, and its activity has been found to increase in insects resistant to insecticides (Papadopoulos et al. 2000). Besides degradation of xenobiotics, GST takes a part in metabolite removal and protection of tissues from damage by free radicals (Papadopoulos et al. 2000).

Previous studies clearly described that host defense-related enzymes play a crucial role by safeguarding the pest from toxins and pathogens. Furthermore, this defense-related enzymes define the fate of target host against invading pathogens (Al Jabr et al. 2018). However, no data are available on the activities of defense-related enzymes in G. mellonella in response to invading fungal pathogen with nematodes.

In this study, the interaction effects between Heterorhabditis zealandica and B. bassiana in the lepidopteran, G. mellonella larvae, individually and/or combined were investigated. The effect of both pathogens on insect enzymatic activity was also studied.

\section{Materials and methods}

\section{Stock culture of G. melonella}

G. mellonella was obtained from the Department of Crop Pests, Plant Protection Research Institute, Agricultural Research Center (ARC), Giza, Egypt. The culture was reared under the laboratory conditions of $28 \pm 2{ }^{\circ} \mathrm{C}$ and $65-70 \%$ R.H. The larvae were reared in glass jars and provided with an artificial diet consisted of wheat flour (200 g), corn flour (200 g), milk powder (100 g), honey $(150 \mathrm{ml})$, yeast powder $(100 \mathrm{~g})$, and glycerol $(150$ $\mathrm{ml})$. The tops of the glass jars were covered by muslin cloth and secured tightly using rubber bands.

\section{Entomopathogenic nematodes}

Heterorhabditis zealandica was cultured in the last instar larvae of G. mellonella according to Dutky et al. (1964). The emerging infective juveniles (IJs) were harvested from White traps and stored in distilled water at $15^{\circ} \mathrm{C}$.

\section{Entomopathogenic fungi}

Fungal isolate of Beauveria bassiana (AUMC 3873) was obtained from Mycological Centre, Assiut University, Assiut, Egypt, and grown on Difco ${ }^{\text {Th }}$ Sabouraud Dextrose Agar in Petri dishes $(90 \mathrm{~mm})$ under a complete dark condition at $28 \pm 1{ }^{\circ} \mathrm{C}$ for 14 days. The conidia were harvested and suspended in a sterile aqueous solution of $0.05 \%$ Tween 80 . Total spore counts were quantified microscopically using a hemocytometer. Serial dilutions were made for different concentrations.

\section{Insect infection}

For concentration-mortality relationship study and determination of median lethal concentration $\left(\mathrm{LC}_{50}\right)$ for both EPN and EPF, 30 individuals of G. mellonella, last larval instar, were divided into 6 replicates; each contained 5 larvae used for infection. For inoculation, each group of larvae was placed in a plastic cup $(9 \mathrm{~cm}$ diameter and $5 \mathrm{~cm}$ deep), filled with 200 -g (oven-dried) soil that moistened with sterile distilled water ( $10 \%$ w/wand) uniformly pipetted on the soil surface with $H$. zealandica concentrations $5,10,20,40$, and $80 \mathrm{IJs} /$ cup or $10,10^{2}, 10^{3}$, 
Table 1 Mortality percentage of the last instar Galleria mellonella larvae exposed to the different concentrations of Heterorhabditis zealandica and Beauveria bassiana in response assay

\begin{tabular}{|c|c|c|c|c|c|c|c|c|c|}
\hline \multicolumn{5}{|l|}{ Heterorhabditis zealandica } & \multicolumn{5}{|c|}{ Beauveria bassiana } \\
\hline $\begin{array}{l}\text { Concentrations (IJs/200 } \\
\text { g soil) }\end{array}$ & $\begin{array}{l}\text { Mean mortality } \\
(\%)\end{array}$ & $\begin{array}{l}\text { Control mortality } \\
(\%)\end{array}$ & $\mathrm{LC}_{50}$ & Slope & $\begin{array}{l}\text { Concentration } \\
\text { (conidia/ml) }\end{array}$ & $\begin{array}{l}\text { Mean mortality } \\
(\%)\end{array}$ & $\begin{array}{l}\text { Control mortality } \\
(\%)\end{array}$ & $\mathrm{LC}_{50}$ & Slope \\
\hline 5 & $40.00^{a}$ & 0.0 & 6.438 & 1.790 & 10 & $26.67^{a}$ & 13.33 & 309.77 & 0.452 \\
\hline 10 & $66.67^{b}$ & & & & $10^{2}$ & $35.29^{\mathrm{ab}}$ & & & \\
\hline 20 & $80^{b d}$ & & & & $10^{3}$ & $66.67^{\mathrm{bc}}$ & & & \\
\hline 40 & $86.67^{\mathrm{cd}}$ & & & & $10^{4}$ & $73.33^{\mathrm{cd}}$ & & & \\
\hline 80 & $93.33^{\mathrm{cd}}$ & & & & $10^{5}$ & $86.67^{d}$ & & & \\
\hline
\end{tabular}

Mortality values within the column followed by the same letter are not significantly different (Duncan's test, $p>0.05$ )

$10^{4}$, and $10^{5}$ spores $/ \mathrm{ml} \mathrm{B.} \mathrm{bassiana} \mathrm{suspensions.} \mathrm{Control}$ cups received sterile distilled water only. After inoculation, cups were incubated at $28{ }^{\circ} \mathrm{C}$. Larval mortality rates were monitored every $24 \mathrm{~h}$ over a period of $96 \mathrm{~h}$, following nematode infection and 10 days for fungal infection.

\section{Nematode-fungus interactions}

To study the interactions between the two tested biocontrol agents, G. mellonella larvae were exposed to $B$. bassiana and $H$. zealandica at concentration of $3.1 \times 10^{2}$ conidia/ml (7 IJs/larvae) respectively, each alone or in various fungus-nematode combinations. The EPN and EPF were applied at the same time, 2, 4 , and 6 days post-EPF infection where mortality rate was assessed, $96 \mathrm{~h}$ post-inoculation. Type of interaction (synergistic, additive, or antagonistic) was determined by using a procedure originally described by Finney (1964) and modified by McVay et al. (1977). The expected additive proportional mortality $M_{\mathrm{E}}$ for the EPN-EPF combinations was calculated by

$$
M_{\mathrm{E}}=M_{\mathrm{Nema}}+M_{\mathrm{Fung}}\left(1-M_{\mathrm{Nema}}\right)
$$

Where $M_{\text {Nema }}$ and $M_{\text {Fung }}$ were the observed proportional mortalities caused by $H$. zealandica and B. bassiana alone, respectively. Results from a $\chi^{2}$ test, $\chi^{2}$ $=\left(M_{\text {NemaFung }}-\mathrm{M}_{\mathrm{E}}\right)^{2} / M_{\mathrm{E}}$, where $M_{\text {NemaFung }}$ was the observed mortality rate for the $H$. zealandica-B. bassiana combination, were compared to the $\chi^{2}$ table value for 1 degree of freedom. If the calculated $\chi^{2}$ values exceeded the table value, there would be a reason to suspect a non-additive effect, that is, synergistic/antagonistic, between the two agents (Finney, 1964). If the differences $M_{\text {NemaFung }}-M_{\mathrm{E}}=D$ had a positive value, a significant interaction was then considered synergistic, and if $D$ had a negative value, a significant interaction was considered antagonistic.

\section{Enzymes preparations}

Enzymes were prepared by homogenization of 10 larvae in 40-ml ice-cold phosphate buffer $(0.05 \mathrm{M}, \mathrm{pH} 7.0)$ by using an ultrasonic homogenizer at $(30 \mathrm{~W}, 10 \mathrm{~s})$. After centrifuging for $30 \mathrm{~min}\left(4^{\circ} \mathrm{C}, 10000 \times g\right)$, the final supernatant was used as an enzyme solution. Protein content of the enzyme solution was measured according to the method of Bradford (1976). All chemicals used were of analytical grade obtained from Sigma.

\section{Determination of enzyme activities}

All experiments were replicated 3 times, each with 10 larvae. Assays also were performed as three technical replicates per preparation for determination of phenoloxidase (PO), glutathione S-transferase (GST) and non-specific esterase (Est) activity. Activities of enzymes were assessed, following the standard methods described by Ishaaya (1971), Habig et al. (1974), and Van Asperen (1962), respectively.

\section{Statistical analysis}

Statistical analysis was performed using Analyze-it software (Analyze-it, Leeds, UK) in accordance with the method of Maxwell and Delany (1989).

\section{Results and discussion}

The present study examined the application of each pathogen alone where the host mortality increased by increasing pathogen concentration. Data of the combined pathogens showed a positive correlation between $H$. zealandica and B. bassiana concentrations and the mortality percentages of the tested last instar G. mellonella larvae. Larval mortality rates by $H$. zealandica increased from 40 to $93.33 \%$ as the dose was increased from 5 to $80 \mathrm{IJs} /$ larva, compared with $0 \%$ in the control at $96 \mathrm{~h}$ post-infection. Whereas, larval mortality rates by B. bassiana increased from 26.67 to $86.67 \%$ as the dose was increased from 10 to $10^{5}$ conidia/ml, 10 days post-infection than the control (13.33\%) (Table 1). 
Table 2 Interactions observed after the combination of Heterorhabditis zealandica (7 IJs/larvae) with Beauveria bassiana (3.1 $\times 10^{2}$ conidia/ml)

\begin{tabular}{llllll}
\hline Pathogens & $\begin{array}{l}\text { Time intervals } \\
(\text { days })\end{array}$ & $\begin{array}{l}\text { Observed mortality } \\
\%\end{array}$ & $\begin{array}{l}\text { Expected mortality } \\
\%\end{array}$ & $x^{2}$ & Interactions \\
\hline Heterorhabditis zealandica $(7 \mathrm{IJs})$ & 0 & $88^{\mathrm{a}}$ & 56.67 & 17.32 & Synergistic \\
+ & 2 & $100^{\mathrm{c}}$ & 50.00 & 50 & Synergistic \\
Beauveria bassiana $3.1 \times 10^{2}$ & 4 & $84^{\mathrm{a}}$ & 53.33 & 17.64 & Synergistic \\
& 6 & $52^{\mathrm{b}}$ & 36.67 & 6.41 & Synergistic \\
\hline
\end{tabular}

Mortality values within the column followed by the same letter are not significantly different (Duncan's test, $p P>0.05$ ). Expected mortality ME $=$ MNema + MMa $\left(1-\right.$ MNema), where MNema and MMa are the observed proportional mortalities caused by $\mathrm{H}$. zealandica $(7 \mathrm{IJs})$ with $\mathrm{B}$. bassiana $\left(3.1 \times 10^{2}\right.$ conidia/ml)

$\mathrm{LC}_{50}$ value reached $6.49 \mathrm{IJ} /$ larva (slope $\left.=1.790\right)$ for H. zealandica infection, while it was $3.1 \times 10^{2}$ conidia $/ \mathrm{ml}$ (slope $=0.452$ ) for B. bassiana.

\section{H. zealandica and B. bassiana interactions}

Synergistic interactions were observed between $H$. zealandica and $B$. bassiana against the last larval instar of G. mellonella (Table 2). The degree of synergy increased, when $H$. zealandica was applied 2 days after fungus infection $\left(\chi^{2}=50\right.$, d.f. $\left.=1, p<0.001\right)$ as compared to the infection at the same time $(\chi 2=17.32$, d.f. $=1, p<0.001)$, 4 days $\left(\chi^{2}=17.64\right.$, d.f. $\left.=1, p<0.001\right)$ or 6 days $\left(\chi^{2}=6.41\right.$, d.f. $=1, p<0.001)$ post-fungal infection.

The current data agree with Molina et al. (2007) and Ansari et al. (2008) who showed that it is possible to establish positive interactions, synergistic by applying EPFs and EPNs at the same time or in short intervals of 2 days with other pests. Bacca and Cesar (2014) found that the percentage of mortality of G. mellonella treated with nematode after 2 days post-fungus infection was higher and statistically different as compared to that of individual treatments.

Ansari et al. (2008) suggested that one of the main factors of a synergistic interaction was the weakening of larvae by an initial fungal infection, which inhibited the larvae from feeding normally. The fungus also increased the host's susceptibility to nematodes by generating a stressful condition, emitted a higher concentration of $\mathrm{CO}_{2}$ in response to fungal colonization that attracted nematodes and altered behavior (Ansari et al. 2008). Ansari et al. (2008) suggested that when the nematodes and fungi are inoculated at the same time, their interaction had an additive effect on host mortality, when the two control agents were acted independently. In this study, however, these effects were not present in any of the application times $(0,2,4$, and 6 days).

\section{Changes in enzyme activities}

Studies of the interactions between EPNs and EPFs with the host's immune system are mainly focused on the effect on prophenoloxidase (Cooper and Eleftherianos, 2016) and the detoxification enzymes glutathione S-transferase and esterase (Kerchev et al. 2017). PO is a key enzyme in insect immunity against pathogens. PO converts phenols to quinones, which subsequently polymerize to form melanin (Cerenius and Soderhall, 2004). Obtained results indicated that G. mellonella responded to fungal infection by a significant increase in PO activity than the control and other treatments. The defensive response to fungal infection leads to elevated levels of PO in hemolymph and other enzyme cascades (Gillespie et al. 2000). Immunization of G. mellonella with the fungus Aspergillus oryazae led to increasing phenoloxidase activity 24-72 h after treatment (Zdybicka-Barabas and Cytrynska, 2010). Mirhaghparast et al. (2013) showed that PO increased significantly after injection of Spodoptera littoralis (Boisd.) larvae by B. bassiana. In stark contrast, $\mathrm{PO}$ activities decreased significantly during the initial period after combined treatment of $H$. zealandica and B. bassiana, suggesting a synergistic interaction in the host. Hiromori and Nishigaki (2001) reported that mixed applications of two pathogens inhibited PO activity in the larvae of the beetle, Anomala cuprea, and the granular cells were suppressed. Yaroslavtseva et al. (2017) observed a reduction of PO

Table 3 Changes in phenoloxidase activity (mean \pm SE) of last instar Galleria mellonella larvae at 12, 24, 36, and 48 h post-infection with Heterorhabditis zealandica, Beauveria bassiana, and their combination

\begin{tabular}{lllll}
\hline Time (h) post-infection & $\begin{array}{l}\text { Control } \\
\text { (O.D. units/min/g.b.wt) }\end{array}$ & $\begin{array}{l}\text { H. zealandica } \\
\text { (O.D. units/min/g.b.wt) }\end{array}$ & $\begin{array}{l}\text { B. bassiana } \\
\text { (O.D. units/min/g.b.wt) }\end{array}$ & $\begin{array}{l}\text { H. zealandica + B. bassiana } \\
\text { (O.D. units/min/g.b.wt) }\end{array}$ \\
\hline $12 \mathrm{~h}$ & $33.86 \pm 1.2^{\mathrm{a}}$ & $32.00 \pm 14^{\mathrm{ac}}$ & $50.30 \pm 1.6^{\mathrm{b}}$ & $29.76 \pm 0.8^{\mathrm{acd}}$ \\
$24 \mathrm{~h}$ & $37.63 \pm 1.3^{\mathrm{a}}$ & $19.10 \pm 05^{\mathrm{b}}$ & $47.70 \pm 1.9^{\mathrm{c}}$ & $16.97 \pm 0.3^{\mathrm{db}}$ \\
$36 \mathrm{~h}$ & $39.20 \pm 1.3^{\mathrm{a}}$ & $12.33 \pm 0.2^{\mathrm{b}}$ & $60.27 \pm 2.3^{\mathrm{c}}$ & $13.33 \pm 0.3^{\mathrm{bd}}$ \\
$48 \mathrm{~h}$ & $45.73 \pm 0.6^{\mathrm{a}}$ & $15.83 \pm 0.4^{\mathrm{b}}$ & $72.20 \pm 2.9^{\mathrm{c}}$ & $8.63 \pm 0.7^{\mathrm{d}}$ \\
\hline
\end{tabular}

Means followed by the same letter in the same row are not significantly different at $p>0.05$ Duncan's multiple range test 
Table 4 Changes in glutathione S-transferase activity in the hemolymph of last instar Galleria mellonella larvae infected with Heterorhabditis zealandica, Beauveria bassiana, and their combination

\begin{tabular}{lllll}
\hline Time (h) post-infection & $\begin{array}{l}\text { Control } \\
\text { (m mole sub. /min g.b.wt) }\end{array}$ & $\begin{array}{l}\text { Heterorhabditis zealandica } \\
\text { (m mole sub. /min g.b.wt) }\end{array}$ & $\begin{array}{l}\text { Beauveria bassiana } \\
\text { (m mole sub. /min g.b.wt) }\end{array}$ & $\begin{array}{l}\text { H. zealandica + B. bassiana } \\
\text { (m mole sub. /min g.b.wt) }\end{array}$ \\
\hline $12 \mathrm{~h}$ & $67.5 \pm 3.8^{\mathrm{a}}$ & $74.17 \pm 1.6^{\mathrm{abd}}$ & $84.73 \pm 3.3^{\mathrm{b}}$ & $139.33 \pm 5.4^{\mathrm{c}}$ \\
$24 \mathrm{~h}$ & $32.8 \pm 1.1^{\mathrm{a}}$ & $99 \pm 1.5^{\mathrm{b}}$ & $36.33 \pm 1.4^{\mathrm{ad}}$ & $120 \pm 5.5^{\mathrm{c}}$ \\
$36 \mathrm{~h}$ & $63.13 \pm 1.6^{\mathrm{a}}$ & $66.2 \pm 1.6^{\mathrm{ab}}$ & $72.17 \pm 2.1^{\mathrm{b}}$ & $102.33 \pm 2.8^{\mathrm{c}}$ \\
$48 \mathrm{~h}$ & $102 \pm 2.1^{\mathrm{a}}$ & $49.03 \pm 1.5^{\mathrm{b}}$ & $123.33 \pm 3.4^{\mathrm{c}}$ & $52.03 \pm 2.3^{\mathrm{db}}$ \\
\hline
\end{tabular}

Means followed by the same letter in the same row are not significantly different at $p>0.05$ Duncan's multiple range test

activity on the third day of combined treatment with the entomopathogenic bacteria $(B t)$ and $M$. anisopliae that was an evidence of strong suppression of beetle of Leptinotarsa decemlineata immunity. Jia et al. (2016) showed a reduction in phenoloxidase activity at the initial period after combined treatment of $M$. anisopliae and diamide insecticide. The authors speculated that the observed interaction might be due to an inhibition of the larval humoral defense and cellular immune systems. Inhibition of $\mathrm{PO}$ in our experiments might also be caused by a weakened humoral defense or cellular immune systems, as a result of the multiplier effect of nematode and fungi together that result in a rapid death within 2 days post-combination.

The phenoloxidase activity in response to $H$. zealandica and $B$. bassiana alone or in combination are shown in Table 3 whereas treatment with $B$. bassiana alone showed an appositive correlation between time post-infection and PO activity reaching 50, 47.70, $60.27 \pm 2.3$, and $72.20 \pm 2.9$ at $12,24,36$, and $48 \mathrm{~h}$, respectively, post-infection as compared to the control and other treatments. While combining of $H$. zealandica with $B$. bassiana and $H$. zealandica alone produced a significant suppressive effect on PO activity over time, which was more significant in response to the joint application, reaching $29.76 \pm 0.8,16.97 \pm 0.3$, $13.33 \pm 0.3$, and $8.63 \pm 0.7$ at $12,24,36$, and $48 \mathrm{~h}$ post-infection, respectively, while in the single infection of $H$. zealandica were $32.00 \pm 14,19.10 \pm 05,12.33 \pm 0.2$, and $15.83 \pm 0.4$ at 12,24 , and $36 \mathrm{~h}$, respectively, over the control and other treatments (Table 3).

In Table 4, individual treatment with $B$. bassiana resulted in a significant increase in glutathione $\mathrm{S}$-transferase activity in time-dependent manner than the control and other treatments, recording $84.73 \pm 3.3,36.33 \pm 1.4,72.17$ \pm 2.1 , and $123.33 \pm 3$ at $12,24,36$, and $48 \mathrm{~h}$ post-infection, respectively, while individual treatments of $H$. zealandica or combination of both $H$. zealandica with $B$. bassiana increased significantly up to $24 \mathrm{~h}$ post-treatment, followed by a decrease in enzyme activity during the later periods as compared to the control and the fungal treatment that reached $74.17 \pm 1.6,99 \pm 1.5,66.2 \pm 1.6$, and $49.03 \pm 1.5$ for $H$. zealandica alone and $139.33 \pm$ 5.4, $120 \pm 5.5, \quad 102.33 \pm 2.8$, and $52.03 \pm 2.3$ for the combination of both $H$. zealandica and B. bassiana at $12,24,36$, and $48 \mathrm{~h}$ post-infection, respectively.

The results in Table 5 revealed that individual treatments with $B$. bassiana resulted in a significant increase in esterase activity at 12,24 , and $36 \mathrm{~h}$ post-infection, reaching $691 \pm 19.8,591 \pm 8.7$, and $637.67 \pm 14.9$, respectively and then induced insignificant difference with the control at $48 \mathrm{~h}$ post-infection $(569 \pm 14.3)$, while the individual treatment with $H$. zealandica and the combination of $H$. zealandica with $B$. bassiana resulted in significant increases in esterase activity in a time-dependent manner as compared to the control. The fungal infection reached $299 \pm 5.9,264 \pm 11.7,512.33 \pm 6.2$, and $1250.33 \pm 55.4$ for H. zealandica and $449 \pm 15.6,562.33 \pm 14.8,1008.33 \pm$ 24.1, and $1104.33 \pm 20.9$ for the combination of both $H$. zealandica with $B$. bassiana at $12,24,36$, and $48 \mathrm{~h}$, respectively, compared to the control and fungal treatment.

Glutathione S-transferase (GST) and esterase (EST) are the major enzymes involved in detoxifying penetrating xenobiotics in insects (Ali et al. 2017). Obtained findings showed an increase in GSTs and ESTs activities during the initial $24 \mathrm{~h}$ and then GSTs decreased sharply later in the joint application and nematode infection, while the ESTs activity remained high. Increased detoxifying enzyme activities against mycoses and other

Table 5 Changes in non-specific esterase activity (mean \pm SE) of last instar Galleria mellonella larvae at 12, 24, 36, and 48 h postinfection with Heterorhabditis zealandica, Beauveria bassiana, and combination them

\begin{tabular}{lllll}
\hline Time (h) post-infection & $\begin{array}{l}\text { Control } \\
\text { (ug a-naphthol/min/g.b.wt) }\end{array}$ & $\begin{array}{l}\text { Heterorhabditis zealandica } \\
\text { (ug a-naphthol/min/g.b.wt) }\end{array}$ & $\begin{array}{l}\text { Beauveria bassiana } \\
\text { (ug a-naphthol/min/g.b.wt) }\end{array}$ & $\begin{array}{l}\text { H. zealandica + B. bassiana } \\
\text { (ug a-naphthol/min/g.b.wt) }\end{array}$ \\
\hline $12 \mathrm{~h}$ & $281.33 \pm 9.4^{\mathrm{a}}$ & $299 \pm 5.9^{\mathrm{a}}$ & $691 \pm 19.8^{\mathrm{b}}$ & $449 \pm 15.6^{\mathrm{c}}$ \\
$24 \mathrm{~h}$ & $247.33 \pm 10.7^{\mathrm{a}}$ & $264 \pm 11.7^{\mathrm{a}}$ & $591 \pm 8.7^{\mathrm{b}}$ & $562.33 \pm 14.8^{\mathrm{b}}$ \\
$36 \mathrm{~h}$ & $427 \pm 17.9^{\mathrm{a}}$ & $512.33 \pm 6.2^{\mathrm{b}}$ & $637.67 \pm 14.9^{\mathrm{c}}$ & $1008.33 \pm 24.1^{\mathrm{d}}$ \\
$48 \mathrm{~h}$ & $502.33 \pm 10.2^{\mathrm{a}}$ & $1250.33 \pm 55.4^{\mathrm{b}}$ & $569 \pm 14.3^{\mathrm{ad}}$ & $1104.33 \pm 20.9^{\mathrm{c}}$ \\
\hline
\end{tabular}

Means followed by the same letter in the same row are not significantly different at $p>0.05$ Duncan's multiple range test 
infections represent the insect's response to bodily intoxication by metabolites or the host-tissue-degrading products of pathogens (Serebrov et al. 2001). Alterations in the activities of GST and ESTs in G. mellonella and L. migratoria infected with EPFs are considered to constitute non-specific body responses to integument damage, induction of additional isoenzymes or fungal toxins (Serebrov et al. 2001). The early activation of non-specific esterases and GST in the hemolymph at the initial stage of acute mycosis was followed by a decrease to control levels (Dubovskiy et al. 2010).

\section{Acknowledgements}

We would like to thank Dr. Reda E.A. Moghaieb (Genetic Engineering Research Center, Faculty of Agriculture, Cairo University, Egypt) for helping in statistical analysis, critical editing of the manuscript.

\section{Funding}

Not applicable

\section{Availability of data and materials}

All datasets are presented in the main manuscript.

\section{Authors' contributions}

SAMl participated in experimental design, practical work, and manuscript writing. HHAS participated in the experimental design and practical work, and coordinated in manuscript writing. MAT participated in discussion and provided intellectual support to this research. All authors read and approved the final manuscript.

\section{Ethics approval and consent to participate}

Not applicable

\section{Consent for publication}

Not applicable

\section{Competing interests}

The authors declare that they have no competing interests.

\section{Publisher's Note}

Springer Nature remains neutral with regard to jurisdictional claims in published maps and institutional affiliations.

\section{Author details}

${ }^{1}$ Agriculture Research Center, Plant Protection Research Institute, Nadi El-said Street-Dokki, Giza, Cairo 12311, Egypt. 'ZZoology Department, Entomology branch, Faculty of Science, AL-Azhar University, Girls Branch, Nasr City, Egypt.

Received: 18 December 2018 Accepted: 21 March 2019

Published online: 03 April 2019

\section{References}

Ali S, Zhang C, Wang Z, Wang XM, Wu JH, Cuthbertson AG, Qiu BL (2017) Toxicological and biochemical basis of synergism between the entomopathogenic fungus Lecanicillium muscarium and the insecticide matrine against Bemisia tabaci (Gennadius). Sci Rep 7:46558

AlJabr A, Hussain A, Rizwan-ul-haq M (2018) Toxin-pathogen synergy reshaping detoxification and antioxidant defense mechanism of Oligonychus afrasiaticus (McGregor). Molecules 23(8):1978

Ansari M, Shah F, Butt T (2008) Combined use of entomopathogenic nematodes and Metarhizium anisopliae as a new approach for black vine weevil, Otiorhynchus sulcatus, control. Entomol Exp Appl 129:340-347

Ansari MA, Tirry L, Moens M (2003) Entomopathogenic nematodes and their symbiotic bacteria for the biological control of Hoplia philanthus (Coleoptera: scarab-aeidae). Biol Control 28:111-117
Bacca T, Lagos B, César T (2014) Effect of Beauveria bassiana and entomopathogenic nematode Steinernema sp. on Galleria mellonella larvae. Boletín Científico Centro de Museos Museo de Historia Natural 18(1):247-258

Bradford MM (1976) A rapid and sensitive method for the quantitation of microgram quantities of protein utilizing the principle of protein-dye binding. Anal Biochem 72:248-254

Cerenius L, Soderhll K (2004) The prophenoloxidase-activating system in invertebrates. Immunol Rev 198:116-126

Cooper D, El eftherianos I (2016) Parasitic nematode immunomodulatory strategies: recent advances and perspectives. Pathogens 5:58

Dutky SR, Thompson JV, Cantwell GE (1964) A technique for the mass propagation of the DD-1 36 nematode. J Insect Pathol 6:417-422

Eleftherianos I, Revenis C (2011) Role and importance of phenoloxidase in insect hemostasis. J innate immunity 3(1):28-33

Fan J, Xie Y, Xue J, Liu R (2013) The effect of Beauveria brongniartii and its secondary metabolites on the detoxification enzymes of the pine caterpillar, Dendrolimus tabulaeformis. J Insect Sci 13:1), 1-1),13

Finney DJ (1964) Probit Analysis. Cambridge University Press, London, UK Gillespie JP, Burnett C, Charnley AK (2000) The immune response of the desert locust Schistoceria gregaria during mycosis of the entomopathogenic fungus, Metarhizium anisopliae var acridum. J Insect Physiol 46:429-437

Gillespie JP, Kanost MR, Trenczek T (1997) Biological mediators of insect immunity. Annu Rev Entomol 42:611-43 11

Grewal P, Ehlers RU, Shapiro-llan DI (eds) (2005) Nematodes as Biological Control Agents. CABI Publishing, Wallingford, UK

Habig WH, Pabst MJ, Jakoby WB (1974) Glutathione S-transferase, the first enzymatic step in mercapturic acid formation. J Biolchem 249:7130-7139

Hemming JD, Lindroth RL (2000) Effects of phenolic glycosides and protein on gypsy moth (Lepidoptera: Lymantriidae) and forest tent caterpillar (Lepidoptera: Lasiocampidae) performance and detoxication activities. Environ Entomol 29(6):1108-1115

Hiromori H, Nishigaki J (2001) Factor analysis of synergistic effect between the entomopathogenic fungus Metarhizium anisopliae and synthetic insecticides. Appl Entomol Zoo 36:231-236

Hussain A, Ming-Yi T (2013) Germination pattern and inoculum transfer of entomopathogenic fungi and their role in disease resistance among Coptotermes formosanus (Isoptera: Rhinotermitidae). Int J Agric Biol 15(2):319-324

Ishaaya I (1971) Observations on the phenoloxidase system in the armored scales Aonidiella aurantii and Chrysomphalus aonidum. Comp Biochemphysiol V39B:935-943

Jia M, Cao G, Li Y, Tu X, Wang G, Nong X, Whitman DW, Zhang Z (2016) Biochemical basis of synergism between pathogenic fungus Metarhizium anisopliae and insecticide chlorantraniliprole in Locusta migratoria (Meyen). Sci Rep 6:28424

Kaya HK, Gaugler R (1993) Entomopathogenic nematodes. Annu Rev Entomol 38:181-206

Kerchev IA, Kryukova NA, Kryukov V, Glupov W (2017) Entomoparasitic nematodes Sychnotylenchus sp. (Anguinidae) on the four-eyed fir bark beetle Polygraphus proximus: effects on the host's immunity and its susceptibility to Beauveria bassiana. ISJ 14:324-329

Laznik Ž, Vidrih M, Trdan S (2012) The effect of different entomopathogens on white grubs (Coleoptera: Scarabaeidae) in an organic hay-producing grassland. Arch Biol Sci 64(4):1235-1246

Maxwell SE, Delaney HD (1989) Designing and analyzing data. Pacific Grove: Brooks/Cole. pp. 475-479

McVay JR, Gudauskas RT, Harper JD (1977) Effect of Bacillus thuringiensis nuclearpolyhedrosis virus mixtures on Trichoplusiani larvae. J Invert Pathol 29:367-372

Mirhaghparast SK, Zibaee A, Hajizadeh J (2013) Effects of Beauveria bassiana and Metarhizium anisopliae on cellular immunity and intermediary metabolism of Spodoptera littoralis Boisduval (Lepidoptera: Noctuidae). Invertebr Surviv J 10:110-119

Molina J, Samuels R, Ribeiro M, Dolinski C (2007) Interactions between isolates of the entomopathogenic fungus Metarhizium anisopliae and the entomopathogenic nematode Heterorhabditis bacteriophora JPM4 during infection of the sugar cane borer Diatraea saccharalis (Lepidoptera: Pyralidae). J Invertebr Pathol 96:187-192

Müller P, Donnelly MJ, Ranson H (2007) Transcription profiling of a recently colonised pyrethroid resistant Anopheles gambiae strain from Ghana. BMC Genomics 8:36

Papadopoulos Al, Boukouvala E, Kakaliouras G (2000) Effect of organophosphate and Pyrethroid insecticides on the expression of GSTs from Tenebrio molitorPupae. Pesticide Biochem Physiol 68:26-33 
Van Asperen K (1962) A study of house fly esterase by means of sensitive colorimetric method. J Insect Physiol 8:401-416

Wraight SP, Carruthers RI, Bradely CA, Jaronski ST, Lacey LA, Wood P, Galaini WSZ (1998) Pathogenicity of entomopathogenic fungi Paecilomyces spp. and Beauveria bassiana against silver whitefly, Bemisia argentifolii. J Inver Pathology 71:217-226

Yaroslavtseva ON, Dubovskiy IM, Khodyrev VP, Duisembekov BA, Kryukov WY, Glupov W (2017) Immunological mechanisms of synergy between fungus Metarhizium robertsii and bacteria Bacillus thuringiensis sp. morrisoni on Colorado potato beetle larvae. J Insect Physiol 96:14-20

Zdybicka-Barabas A, Cytryńska M (2010) Phenoloxidase activity in hemolymph of Galleria mellonella larvae challenged with Aspergillus oryzae 2, pp 49-57

\section{Submit your manuscript to a SpringerOpen ${ }^{\circ}$ journal and benefit from:}

- Convenient online submission

- Rigorous peer review

- Open access: articles freely available online

- High visibility within the field

- Retaining the copyright to your article

Submit your next manuscript at $\boldsymbol{\nabla}$ springeropen.com 